\title{
THE RELATIONSHIP BETWEEN SEAGRASS Thalassia hemprichii PERCENTAGE COVER AND THEIR BIOMASS
}

\author{
Andi Mallombasi ${ }^{1}$, Supriadi Mashoreng ${ }^{1}$, Yayu A. La Nafie ${ }^{1 *}$ \\ Submitted: March 15, 2020 Accepted: March 24, 2020 \\ ${ }^{1}$. Department of Marine Science, Faculty of Marine Science \& Fisheries, University of Hasanuddin \\ Corresponding author: \\ *Yayu A. La Nafie \\ Email: yayulanafie@yahoo.com
}

\begin{abstract}
Seagrass has many functions and values, including as carbon sink. However, to estimate carbon in seagrass, it involves seagrass biomass harvesting which is laborious, costly, and destructive. This study aimed to find out the relationship between seagrass Thalassia hemprichii percent cover with their biomass which will provide alternative method for biomass estimation leading to an efficient, less cost and less destructive method for seagrass carbon stock estimation. Seagrass were sampled in Bonebatang island, South Sulawesi, and estimated their percent cover following SeagrassWatch Method from different seagrass condition and sediment type, as well as harvested for their biomass. In the lab, seagrass biomass was dried. Data was analyzed by using simple regression analysis. Results showed that there is a relatively strong relationship between percent cover and the belowground, aboveground and total biomass $\left(\mathrm{R}^{2}=\right.$ $0.70 ; 0,81$ and 8,3, respectively). Seagrass percent cover (seagrass health status, i.e. healthy, moderate and poor) also resulted a relatively strong influence on total seagrass biomass (R2>50\%). However, apart from segarss percent cover, some other parameters are needed to be taken into consideration, such as seagrass densities and seagrass morphologies
\end{abstract}

Keywords: Seagrass cover, Seagrass biomass, Thalassia hemprichii, Bonebatang island, Carbon Stock

\section{INTRODUCTION}

Seagrass beds are shallow water ecosystems found in all waters around the globe (except the antarctica) (Short et al., 2007). They have many important functions and values, such as for breeding, feeding, and shelter for many marine organisms, as well as being a coastal defense from high hydrodynamics. Apart from that, they are also important for storing carbon (Alongi et al., 2016).

The $\mathrm{CO} 2$ absorbed by seagrass vegetation is used for photosynthesis which indirectly reduced carbon emission in the atmosphere. Carbon absorbed is stored in the form of carbon in live seagrass tissues (leaves, roots and rhizomes) (Supriadi et al., 2014). Seagrass ecosystem is a highly productive ecosystem (Azkab 2000), which refers to the increasing of biomass (dried weight) in certain area and time $\left(\mathrm{gr} \mathrm{m}^{-2} \mathrm{day}^{-1}\right)$. Hence, when converted to carbon production, seagrass may produce 500-1000 $\mathrm{gC} \mathrm{m}^{-2}$ year $^{-1}$ and may even double to that value.

Nowadays, the role of seagrass ecosystem as carbon sink is becoming more important. However, to measure carbon content in seagrass biomass is still inefficient, high-cost and destructive, since one part of the procedure is to

harvest seagrass. Therefore, there is a need to an effective, low-cost and less-destructive method.

One parameter measured in seagrass ecosystem which assumed to have a relationship with seagrass biomass is percent cover. By acknowledging seagrass percent cover, the total carbon stock in seagrass biomass should be recognized.

This research aimed to find out the relationship between seagrass Thalassia hemprichii percent cover and their biomass and expected to be used in estimating seagrass biomass in other sites based on the percent cover. It is expected that this can be used as an alternative method in estimating carbon storage in efficient, less cost and less destructive.

\section{MATERIALS AND METHODS}

\section{Study site}

This research was conducted in Bonebatang island, Makassar, South Sulawesi (Fig. 1).

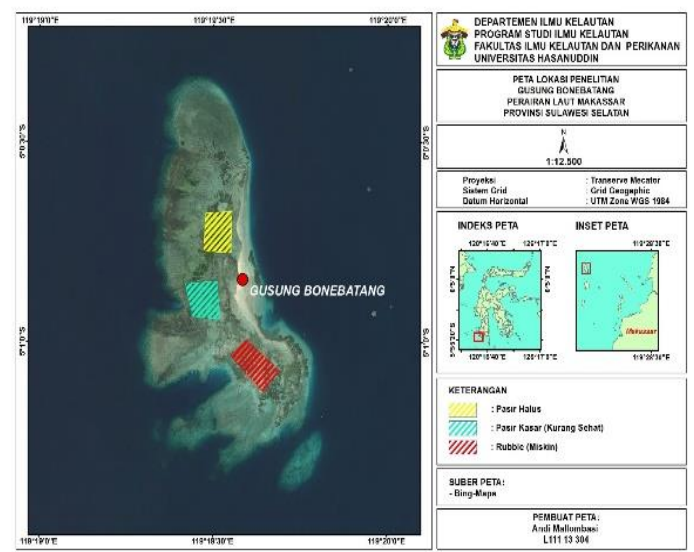

Figure 1. Study site in Bonebatang island 
The bed was selected through direct observation and were mainly dominated by Thalassia hemprichii (Priosambodo, 2014).

\section{Seagrass Percentage Cover Estimation}

Seagrass percentage cover estimation was conducted following McKenzie et al. (2001). Observation was based on T. hemprichii percentage cover category as stated in the Minister of Environment Decree No. 200 year 2004 (Kepmen LH No. 200 Tahun 2004) (Table 1). Each seagrass percentage cover found in quadrat $\left(30 \times 30 \mathrm{~cm}^{2}\right)$ was estimated and repeated in different quadrats (3-5 times) and in different types of sediment, i.e. rubble, coarse sand, fine sand.

Table 1. Seagrass status (Kepmen LH No. 200/2004)

\begin{tabular}{lll}
\hline Seagrass Condition & $\begin{array}{l}\text { Coverage } \\
(\%)\end{array}$ \\
\hline Good & Rich/healthy & $\geq 60$ \\
\hline \multirow{2}{*}{ Damaged } & $\begin{array}{l}\text { Less rich/ less } \\
\text { healthy/moderate } \\
\end{array}$ & $30-59,9$ \\
& Poor & $\leq 29,9$ \\
\hline
\end{tabular}

\section{Seagrass Biomass Sampling}

Seagrass T. hemprichii were sampled after estimating the percentage cover in each quadrate by using a spade. Seagrass biomass were then cleaned from sediment and rinsed with seawater directly. Samples were put in an ice box to be kept fresh then taken to the marine laboratory, Department of Marine Science, Hasanuddin University.

In the lab, samples were separated from above ground (leaves) and below ground biomass (roots and rhizomes). Epiphytes found on the samples, were scraped by using a blade. Samples were labeled then dried in an electric oven $\left(70^{\circ} \mathrm{C}\right)$ until constantly dried \pm 48 hours.

Subsequently, dried biomass samples were weighed and the values then converted to an area of a square meter for each seagrass coverage category.

\section{Data Analysis}

The relationship between seagrass Thalassia hemprichii percentage cover and their biomass were analyzed by using simple linier regression.

\section{RESULTS AND DISCUSSION}

It is acknowledged that there is a relationship between seagrass percentage cover and their biomass. However, information on this relationship to certain species such as Thalassia hemprichii, is still lacking, which will be discussed.

\section{Seagrass Thalassia hemprichi Percentage Cover and Biomass}

Like many other islands in the Spermonde archipelago, seagrass in Bonebatang island can be found forming a meadow or only in patches or both meadows and patches. Seagrasses are distributed all around the island with various percentage cover. Following the percentage cover stated by Kepmen LH No. 200 tahun 2004, seagrass in Bonebatang fell into 3 categories, healthy, moderate and poor (Table 2).

Tabel 2. Seagrass Thalassia hemprichii Percentage cover category/Status and Biomass in Bonebatang island

\begin{tabular}{llll}
\hline $\begin{array}{l}\text { Seagrass } \\
\text { Percent Cover } \\
\text { Category/Status }\end{array}$ & \multicolumn{2}{l}{ Biomassa (gr) } & Ratio \\
\cline { 2 - 4 } & AG & BG & \\
\hline Healthy & 128.33 & 486.54 & $1: 3.79$ \\
Moderate & 74.23 & 293.27 & $1: 3.95$ \\
Poor & 40.42 & 165.57 & $1: 4.10$ \\
\hline Note : AG = Aboveground BG = Belowground
\end{tabular}

Table 2 showed that belowground (BG) biomass was bigger than aboveground (AG). This was due to the seagrass T.hemprichii that required more robust and stronger rooting to support seagrass leaves to prevent being uprooted by waves, especially in low percentage cover (poor). It also showed that seagrass biomass was directly proportional to the percent seagrass cover, i.e. the healthier the seagrass, the more biomass, both above and belowground. In addition, belowground biomass acted as a storage for photosynthetic organic material and the largest nutrient absorption was in the rhizomes which constitutes $60-80 \%$ of seagrass biomass. Hence, it could support seagrass growth when photosynthesis process was not optimal (Alcoverro et al. 2001).

Tabel 3. Seagrass Biomass based on sediment type.

\begin{tabular}{llll}
\hline \multirow{2}{*}{$\begin{array}{l}\text { Sediment } \\
\text { type }\end{array}$} & \multicolumn{2}{l}{ Biomass (gr) } & \multirow{2}{*}{ Ratio } \\
\cline { 2 - 3 } & AG & BG & \\
\hline Rubble & 40.21 & 167.45 & $1: 4.16$ \\
$\begin{array}{l}\text { Coarse } \\
\text { sand }\end{array}$ & 55.69 & 224.87 & $1: 4.04$ \\
Fine sand & 119.0 & 417.48 & $1: 3.51$ \\
\hline
\end{tabular}

Seagrass biomass differ according to their sediment type (Tabel 3). Seagrass growing in rubble substrate had the highest ratio of above and belowground biomass, whereas the lowest were seagrass growing in fine sand substrate. This indicated that the softer the sediment type, the less biomass (especially belowground) which may be related to seagrass adaptation. Seagrass growing in carbonate sediment is also an adaptation to live in low nutrient content. 
Hence, having more roots (increasing belowground biomass) may be an adaptation to increase nutrient absorption. Rubble type of sediment indicate a high hydrodynamic. Hence, having more belowground biomass would be a strategy to cope with the environment (La Nafie, et al., 2012).

\section{Relationship between Seagrass percent cover and their biomass}

Figure 2 showed a relationship between percent cover and the total biomass (both above and belowground) $\left(\mathrm{R}^{2}=0.70 ; 0,81\right.$ and 8,3 for belowground, aboveground and total biomass, respectively). This indicated that there is a relatively strong relationship between percent cover and the total biomass compare to above and belowground biomass, independently

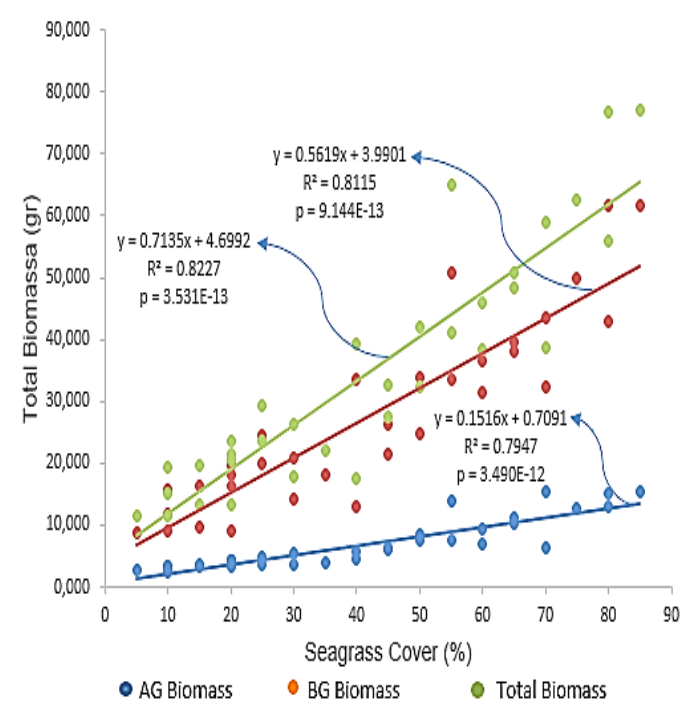

Figure 2. Regression analysis between seagrass percent cover and above ground (AG), belowground (BG) and total biomass

Relationship between seagrass cover (\%) and Aboveground (AG) Biomass of different seagrass cover category

Healthy seagrass coverage category showed a relatively moderate relationship between seagrass percentage cover and aboveground biomass $\left(\mathrm{R}^{2}=\right.$ $0.5137)$, followed by the poor seagrass percentage cover $\left(\mathrm{R}^{2}=0.5876\right)$. Moderate percentage cover however, had a higher correlation with aboveground biomass $\left(\mathrm{R}^{2}=0.6023\right)$. It indicated that the effect of percentage cover on aboveground biomass was $60 \%$ (Figure 3). Overall, all biomass showed a correlation with seagrass percent cover with all $\mathrm{R}^{2}$ values bigger than $50 \%$.

\section{Relationship between seagrass percent cover and Belowground (BG) Biomass of different seagrass cover category}

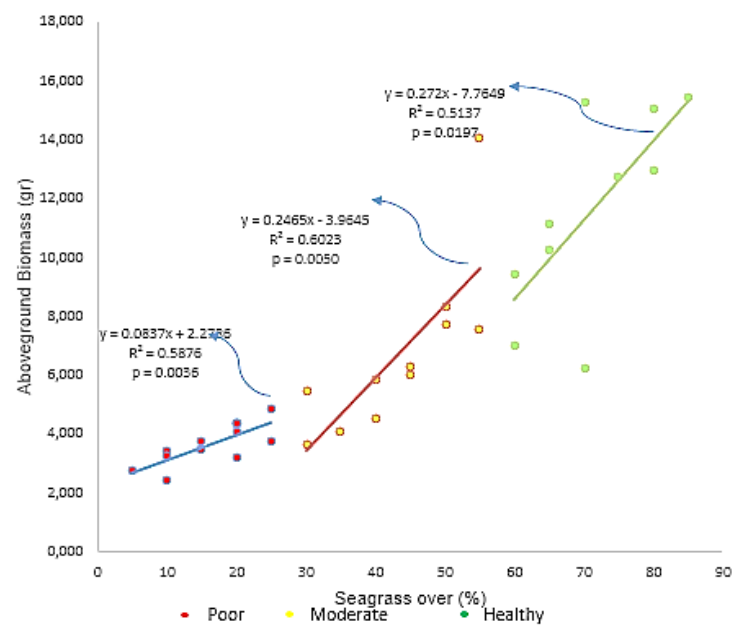

Figure 3. Regression analysis between seagrass percent cover and aboveground (AG) Biomass of different seagrass cover category

The relationship between poor seagrass cover and belowground biomass showed a relatively moderate correlation $\left(\mathrm{R}^{2}=0,51\right)$ indicating a $51 \%$ of linearity of seagrass cover influence on belowground biomass. This was followed by moderate seagrass cover $\left(\mathrm{R}^{2}=0.5339\right)$ and healthy seagrass cover $\left(\mathrm{R}^{2}\right.$ $=0.6979)$. The latter showed a relatively high percentage of linearity (61\%) compare to others.

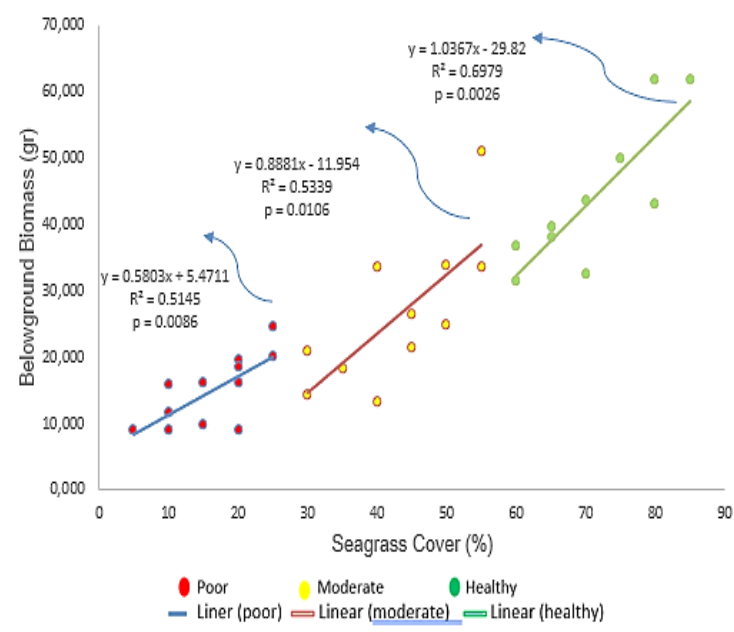

Figure 4. Regression analysis between seagrass percent cover and belowground (BG) Biomass of different seagrass cover category

Regression analysis (Fig. 4) showed a relationship between seagrass percent cover and total biomass. Healthy seagrass showed a relatively strong relationship $\left(\mathrm{R}^{2}=0.6878\right)$, compared to moderate $\left(\mathrm{R}^{2}=0,563\right)$ and poor seagrass percent cover $\left(\mathrm{R}^{2}=\right.$ $0,577)$. However, all of the seagrass percent cover category (healthy, moderate and poor) had a relatively strong influence on total seagrass biomass $\left(\mathrm{R}^{2}>50 \%\right)$. Seagrass percent cover was positively correlated with the total biomass. In poor seagrass percent cover category, the average percent cover 
was $16,25 \%$, and the biomass was 18,539 gr. Whereas in moderate $(43,18 \%)$ and healthy seagrass cover $(71 \%)$ the total biomass were 33,07 gr and 55,34 gr, respectively. The more percent cover, the higher the biomass (Larasanti, et al. (2015); Arifa, et al. (2013)). This relationship was due to seagrass canopy that may affect the biomass of the leaves, roots and rhizomes. The higher number of shoots covering the substrates indicated more rhizomes and roots that resulted higher belowground biomass. Higher belowground biomass was also needed to prevent from uprooting due to high hydrodynamics. However, regarding carbon stock, it is important to note that percent cover is like other parameters (such as seagrass density), when the value is high, it may not necessarily result in higher biomas (Irawan, 2017). This may be due to different seagrass morphologies of different species. Higher percent cover for small size seagrass may result a lower biomass compare to low percent cover of big size seagrass.

\section{CONCLUSION}

There is a positive and linear relationship between seagrass Thalassia hemprichii percent cover and their biomass, and the better status of seagrass cover, the higher the value of $\mathrm{R}^{2}$.

\section{ACKNOWLEDGMENT}

The authors would like to thank Arfan Hamka, Ayu Lestari and Rahima Rahman for their assistance in the field, as well as to M. Safah Thalib and Abdillah Salihin for assisting in providing the map.

\section{REFERENCES}

Alcovero, T., M Manzanera and J Romero.2001. Annual metabolic carbon balance of the seagrass Posidonia oceanica: The importance of carbohydrate reserves. Mar Ecol Prog Ser 211: 105-116.

Alongi DM, D Murdiyarso, JW Fourqurean, JB Kauffman, A Hutahaean, S Crooks, CE Lovelock, J Howard, D Herr, M Fortes, E Pidgeon, T Wagey. 2016. Indonesia's blue carbon: a globally significant and vulnerable sink for seagrass and mangrove carbon.
Wetlands Ecology and Management 24 (1): 3-13.

Dini A, A Pratomo, and Muzahar. 2013. Biomassa Padang Lamun di Perairan Desa Teluk Bakau Kabupaten Bintan Provinsi Kepulauan Riau. Journal. Fakultas Ilmu Kelautan dan Perikanan, Universitas Maritim Raja Ali Haji.

Azkab, M.H. 2000. Struktur dan Fungsi Komunitas Lamun, Oseana, Volume XXV, Nomor 3: 9-17. Balitbang Biologi Laut, PustlibangBiologi Laut-LIPI, Jakarta.

Keputusan Menteri Negara Lingkungan Hidup. Kriteria Baku. 2004. Kerusakan dan Pedoman Penentuan Status Padang Lamun. Keputusan Menteri Negara Lingkungan Hidup Nomor 200 tahun 2004.

La Nafie YA, CB de los Santos, FG Brun, M van katwijk, TJ Bouma. 2012. Waves and High Nutrient Loads Jointly Decreased Survival and Separately affect Morphological and Biomechanical Properties of Seagrass Zostera noltii, Limnol. Oceanogr., 57(6): 1554-1672.

Larasanti M, F Lestari, and LW Zen. 2015. Kajian Biomassa Lamun di Kawasan Konservasi Laut Daerah Desa Malang Rapat Kabupaten Bintan. Jurusan Menejemen Sumberdaya Perairan. FIKP. Umrah. Tanjungpinang

McKenzie LJ, MA Finkbeiner, H Kirkman. 2001. Methods for mapping seagrass distribution. In: Short FT, Coles RG, editor. Global Seagrass Research Methods. Amsterdam: Elsevier Science B.V. pp: 101-121.

Priosambodo D. 2014. Sebaran Spasial Komunitas Lamun di Pulau Bonebatang Sulawesi Selatan. Vol.III No.2:165-175.

Short FT, TJB Carruthers, WC Dennison, M Waycott. 2007. Global seagrass distribution and diversity: a bioregional model. Journal of Experimental Marine Biology and Ecology 350, 3-20.

Supriadi, RF Kaswadji, DG Bengen, M Hutomo. 2014. Carbon Stock of Seagrass Community in Barranglompo Island, Makassar. Indonesian Journal of Marine Science (19): $1-10$. 